\title{
Effect of Vitamin D Supplementation and Calcium in Reducing the Risk of Preeclampsia: Meta-Analysis
}

\author{
Fanny Kartika Fajriyani'), Eti Poncorini Pamungkasari²), Bhisma Murti') \\ Masters Program in Public Health, Universitas Sebelas Maret \\ Faculty of Medicine, Universitas Sebelas Maret
}

\section{ABSTRACT}

Background: Preeclampsia (PE) is a major complication in pregnancy and a major cause of maternal and fetal morbidity and mortality. Analysis of risk factors and prevention of preeclampsia are needed to reduce the adverse effects of preeclampsia. Important supplements during pregnancy to prevent the increase in blood pressure of pregnant women are Vitamin $\mathrm{D}$ and calcium. This study aimed to analyze the effect of vitamin D and calcium supplementation on reducing the risk of preeclampsia.

Subjects and Method: This study is a metaanalysis of a number of randomized controlled trials. The articles used in this study were obtained from several databases including PubMed, Google Scholar, Springerlink, and Sciencedirect. The articles used in this study were those published from 2002-2020. The article search was carried out by considering the eligibility criteria defined using the PICO model. P: Pregnant women, I: vitamin D and calcium, C: placebo, and O: preeclampsia. The keywords to find articles are as follows: "Vitamin D" OR "Calcium" OR "Vitamin D and Calcium" AND "preeclampsia" AND "Randomized Controll Trials". The articles included in this study are full text articles with Cross- sectional study design. Articles were collected using PRISMA flow diagrams. Articles were analyzed using the Review Manager 5.3.

Results: A total of 9 articles were reviewed in this study. The meta-analysis showed that vitamin D supplementation reduced the risk of preeclampsia in pregnant women $(\mathrm{RR}=0.45$, 95\% CI 0.32-0.63, p<0.001). The meta-analysis of 8 articles also showed that calcium supplementation reduced the risk of preeclampsia in pregnant women with calcium $(\mathrm{RR}=0.42 ; 95 \%$ $\mathrm{CI}=0.31-0.57 ; \mathrm{p}<0.001)$. This meta-analysis combines primary research from Iran, India, Bangladesh, South Africa, Cameroon, and Saudi Arabia.

Conclusion: Vitamin D and calcium supplementation reduces the risk of preeclampsia.

Keywords: vitamin D, Calcium, preeclampsia, randomized controlled trial

\section{Correspondence:}

Fanny Kartika Fajriyani. Masters Program in Public Health, Universitas Sebelas Maret, Jl. Ir. Sutami 36A, Surakarta 57126, Central Java. Email: fannykfa9@gmail.com.

Cite this as:

Fajriyani FK, Pamungkasari EP, Murti B (2020). Effect of Vitamin D Supplementation and Calcium in Reducing the Risk of Preeclampsia: Meta-Analysis. Indones J Med. 05(04): 308-320. https://doi.org/10.26911/theijmed.2020.05.04.06.

(c) (i) (2) Indonesian Journal of Medicine is licensed under a Creative Commons (c)

\section{BACKGROUND}

Preeclampsia (PE) is a major complication in pregnancy and a major cause of maternal and fetal morbidity and mortality. The World Health Organization (WHO) reports that the prevalence of pregnant women with hypertension is around 35-55\% and it increases with increasing gestational age, WHO also states that the preeclampsia rate is between $5-10 \%$ of all pregnancies (WHO, 2017).

Preeclampsia in pregnancy is defined as the occurrence of hypertension as well as the presence of proteinuria in women after 
20 weeks of gestation. Most of the maternal deaths caused by preeclampsia occur in developing countries and countries with low to middle income populations. The biggest impact of preeclampsia occurs in developing countries where the incidence of preeclampsia is $20-80 \%$ of the maternal mortality rate (Dodd et al, 2014).

Preeclampsia is still a theoretical disease. Various studies have not been able to clearly penetrate the exact cause. The widely held theories are: (1) placental vascularization disorders; (2) placental ischemia, free radicals and endothelial dysfunction;(3) immunological intolerance between mother and fetus; (4) cardiovascular adaptation; (5) malnutrition; and (6) inflammation (Cunningham et al., 2014).

Analysis of risk factors for preeclampsia is needed to reduce the adverse effects of preeclampsia. The theory of nutrition is one of the theories adopted and during pregnancy there will be changes in the mother's metabolism. Important supplements during pregnancy to prevent an increase in blood pressure for pregnant women are calcium and vitamin D (Khaing et al., 2018).

The role of calcium in the development of the risk of preeclampsia during pregnancy can be explained by low calcium levels or other factors during pregnancy resulting in increased blood pressure. Pregnant women with high calcium intake have stable blood pressure levels which will prevent hypertension, thereby reducing the risk of preeclampsia (Bhutta et al, 2012).

This study aimed to examine the effect of vitamin D and calcium supplementation on reducing pre-eclampsia.

\section{SUBJECTS AND METHOD}

\section{StudyDesign}

This was a systematic review and meta-analysis. The articles used in this study were obtained from several databases including PubMed, Google Scholar, Springerlink, and Sciencedirect. Keywords to find articles are as follows: "Vitamin D" OR "Calcium" OR "Vitamin D and Calcium" AND "Preeclampsia" AND "Randomized Controll Trials"

\section{InclusionCriteria}

The articles included in this study are full paper articles with randomized controlled trials study design and in English. Appropriate articles should mention the population of pregnant women, vitamin $\mathrm{D}$ and calcium interventions with the outcome of preeclampsia. Articles must be published in 2002-2020 with multivariate Relative Risk.

\section{Exclusion Criteria}

Articles excluded in this study were articles with pregnant women with gestational hypertension and articles with results not randomized controlled trials.

\section{Operational definition of variables}

The article search was carried out by considering the eligibility criteria defined using the PICO model. The population in the study were pregnant women with intervention in the form of vitamin D and calcium, the comparison was placebo and outcomes in the form of preeclampsia.

Preeclampsia were pregnant women with gestational age above 20 weeks where blood pressure systole $>140$, diastole $>90$ and urine protein + .

Calcium and vitamin $\mathbf{D}$ were given at gestational age with a calcium dose of 1,000-2,000 mg per day and vitamin D as much as 2000 IU per day.

\section{Data Analysis}

Data processing was carried out by the RevMan 5.3 by calculating the effect size and heterogeneity to determine which research model was combined and formed the final meta-analysis result. 
Fajriyani et al./ Vitamin D and Calcium Supplementation in Reducing Preeclampsia

\section{RESULTS}

The process of searching for articles is carried out by searching through a database with journals as shown in Figure 1. The selected articles came from Africa (2 studies) and Asia (14 articles).

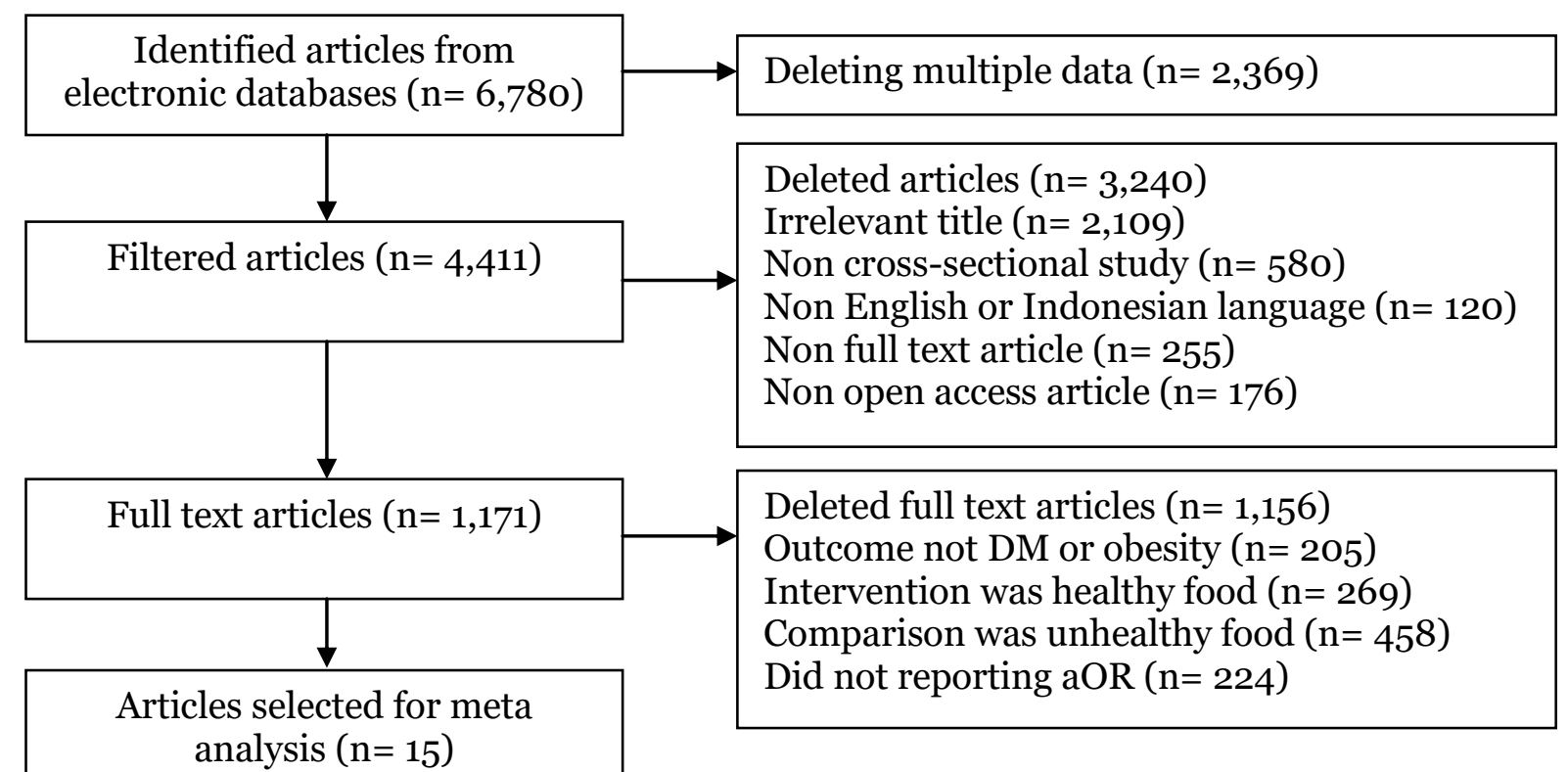

Figure 1. PRISMA flow diagram

\section{Vitamin D supplementation on the incidence of preeclampsia in pregnant women}

a. Forest Plot

\begin{tabular}{|c|c|c|c|c|c|c|c|c|c|c|c|c|}
\hline Study or Subgroup & \multicolumn{2}{|c|}{ Vitamin D } & \multicolumn{2}{|c|}{ plasebo } & \multicolumn{2}{|r|}{ Risk Ratio } & \multicolumn{6}{|c|}{$\begin{array}{c}\text { Risk Ratio } \\
\text { IV, Fixed, } 95 \% \mathrm{Cl}\end{array}$} \\
\hline Ali 2017 & 1 & 83 & 6 & 81 & $2.7 \%$ & $0.16[0.02,1.32]$ & & & & & & \\
\hline Asemi 2013 & 0 & 27 & 1 & 27 & $1.2 \%$ & $0.33[0.01,7.84]$ & & & & & & \\
\hline Jamilian 2015 & 2 & 30 & 3 & 30 & $4.1 \%$ & $0.67[0.12,3.71]$ & & & & & & \\
\hline Karamali 2015 & 1 & 30 & 3 & 30 & $2.5 \%$ & $0.33[0.04,3.03]$ & & & & & & \\
\hline Naghshineh 2016 & 2 & 70 & 7 & 70 & $5.1 \%$ & $0.29[0.06,1.33]$ & & & & & & \\
\hline roth 2015 & 1 & 80 & 0 & 80 & $1.2 \%$ & $3.00[0.12,72.56]$ & & & & & & \\
\hline Sablok 2015 & 22 & 120 & 25 & 60 & $51.8 \%$ & $0.44[0.27,0.71]$ & & & & & & \\
\hline Samimi 2017 & 1 & 30 & 3 & 30 & $2.5 \%$ & $0.33[0.04,3.03]$ & & & & & & \\
\hline Sasan 2017 & 11 & 70 & 22 & 72 & $28.9 \%$ & $0.51[0.27,0.98]$ & & & & & & \\
\hline Total $(95 \% \mathrm{Cl})$ & & 540 & & 480 & $100.0 \%$ & $0.45[0.32,0.63]$ & & & & & & \\
\hline Total events & 41 & & 70 & & & & & & & & & \\
\hline $\begin{array}{l}\text { Heterogeneity: } \mathrm{Chi}^{2}= \\
\text { Test for overall effect }\end{array}$ & $\begin{array}{l}3.16, \mathrm{df}= \\
\mathrm{Z}=4.53(\end{array}$ & $\begin{array}{l}8(P= \\
(P<0.0\end{array}$ & $\begin{array}{l}0.92) ; 1^{2}= \\
0001)\end{array}$ & & & & 0.01 & & itamin D & Plasebo & 10 & 100 \\
\hline
\end{tabular}

Figure 2. Forest plot of the effect of vitamin D supplementation on reducing the risk of preeclampsia 
Fajriyani et al./ Vitamin D and Calcium Supplementation in Reducing Preeclampsia

Meta-analysis can be seen through a forest plot (Figure 2) showing that vitamin D supplementation has an effect on reducing the risk of preeclampsia. The results of the RCT meta-analysis showed that vitamin D supplementation reduced the risk of preeclampsia by 0.45 times compared to placebo and was statistically significant ( $p$ $<0.001)$. The heterogeneity of the research data shows $\mathrm{I}^{2}=0 \%$ so that the distribution of data is declared homogeneous (fixed effect model).

\section{b. Funnel Plot}

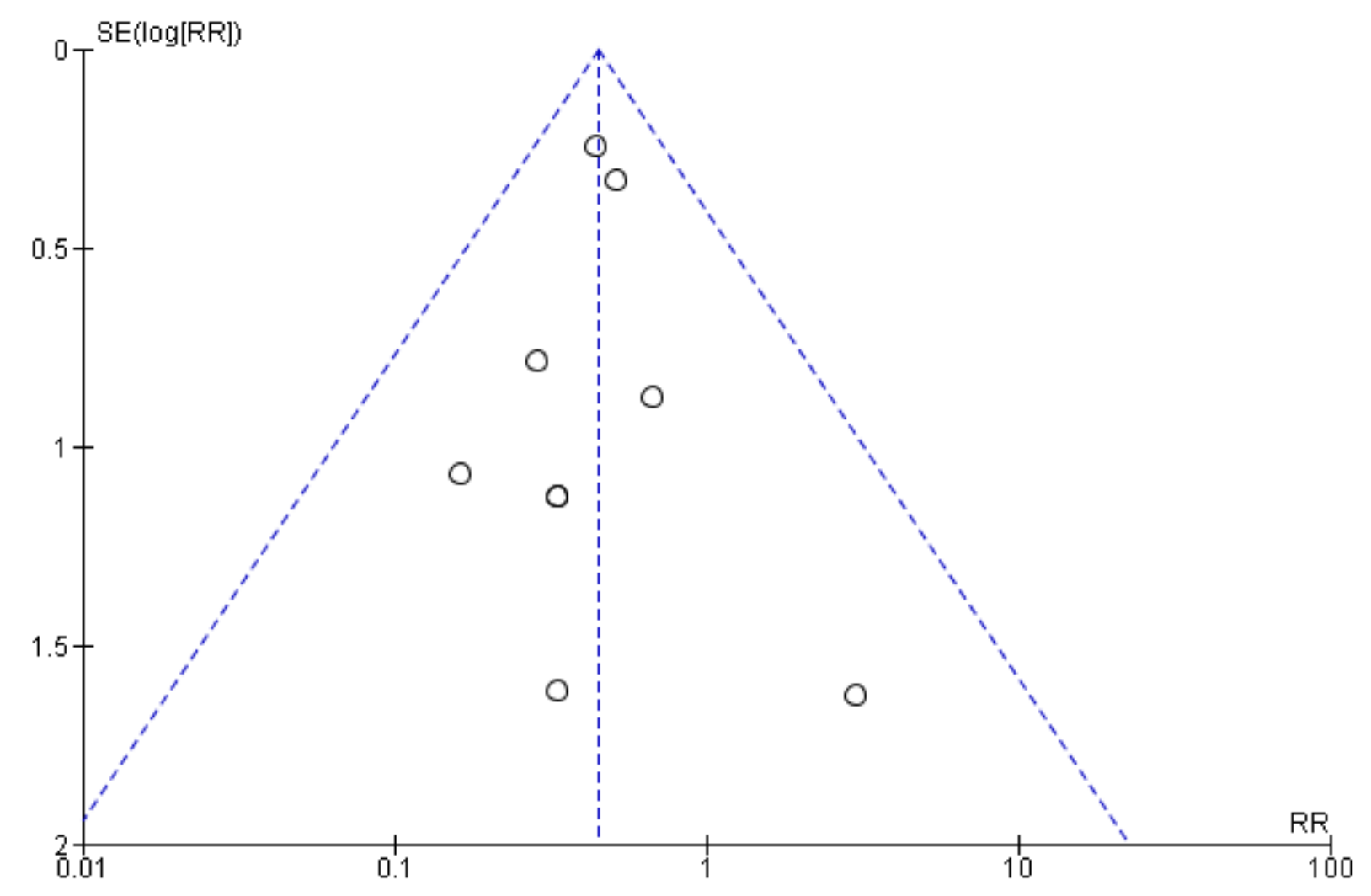

Figure 5. Funnel plot of the effect of vitamin D supplementation on reducing the risk of preeclampsia
Based on Figure 2, it shows that there is a publication bias which is characterized by asymmetry of the right and left plots where 4 plots are on the right, 3 plots are on the left and 1 plot touches the line. The plot on the left of the graph appears to have a standard error between 0.5 and 1.5 and the plot on the right has a standard error between 0.5 and 2. The bias also occurs from an imbalance between the distances between studies on both the right and left of the funnel plot. 
Fajriyani et al./ Vitamin D and Calcium Supplementation in Reducing Preeclampsia

\section{c. Summary Source}

\section{Table 1. Descriptions of primary studies included in the meta-analysis}

\begin{tabular}{|c|c|c|c|c|c|}
\hline $\begin{array}{l}\text { Author } \\
\text { (Year) }\end{array}$ & Title & Country & $\begin{array}{l}\text { Study } \\
\text { Design }\end{array}$ & Sample & $\begin{array}{c}P \\
\text { Popula- } \\
\text { tion }\end{array}$ \\
\hline $\begin{array}{l}\text { Sasan et } \\
\text { al.(2017) }\end{array}$ & $\begin{array}{l}\text { The Effects of Vitamin D Supplement on Prevention } \\
\text { of Recurrence of Preeklampsia in Pregnant Women } \\
\text { with a History of Preeklampsia }\end{array}$ & Iran & $\mathrm{RCT}$ & 142 & $\begin{array}{l}\text { Pregnant } \\
\text { women }\end{array}$ \\
\hline $\begin{array}{l}\text { Samimi et } \\
\text { al.(2017) }\end{array}$ & $\begin{array}{l}\text { The effects of vitamin D plus calcium supplemen- } \\
\text { tation onmetabolic profiles, biomarkers of inflam- } \\
\text { mation, oxidative stress and pregnancy outcomes in } \\
\text { pregnant women at riskfor pre-eclampsia }\end{array}$ & Iran & $\mathrm{RCT}$ & 60 & $\begin{array}{l}\text { Pregnant } \\
\text { women }\end{array}$ \\
\hline $\begin{array}{l}\text { Sablok et al. } \\
(2015)\end{array}$ & $\begin{array}{l}\text { Supplementation of Vitamin D in pregnancy and its } \\
\text { correlation with feto-maternal outcome. }\end{array}$ & India & $\mathrm{RCT}$ & 165 & $\begin{array}{l}\text { Pregnant } \\
\text { women }\end{array}$ \\
\hline $\begin{array}{l}\text { Roth et al. } \\
\text { (2013) }\end{array}$ & $\begin{array}{l}\text { Randomized plasebo-controlled trial of high-dose } \\
\text { prenatal third-trimester vitamin D3 } \\
\text { supplementation in Bangladesh: }\end{array}$ & $\begin{array}{l}\text { Bangla- } \\
\text { desh }\end{array}$ & $\mathrm{RCT}$ & 160 & $\begin{array}{l}\text { Pregnant } \\
\text { women }\end{array}$ \\
\hline $\begin{array}{l}\text { Karamali et } \\
\text { al. (2015) }\end{array}$ & $\begin{array}{l}\text { Effects of high-dose Vitamin D supplementation on } \\
\text { metabolic status and pregnancy outcomes } \\
\text { inpregnant women at risk for pre-eclampsia }\end{array}$ & Iran & $\mathrm{RCT}$ & 60 & $\begin{array}{l}\text { Pregnant } \\
\text { women }\end{array}$ \\
\hline $\begin{array}{l}\text { Naghshineh } \\
\text { et al. (2016 }\end{array}$ & $\begin{array}{l}\text { Effect of vitamin D supplementation in the reduce } \\
\text { risk of preeklampsia in nulliparous women }\end{array}$ & Iran & $\mathrm{RCT}$ & 60 & $\begin{array}{l}\text { Pregnant } \\
\text { women }\end{array}$ \\
\hline $\begin{array}{l}\text { Jamilian et } \\
\text { al. (2015) }\end{array}$ & $\begin{array}{l}\text { The effects of vitamin D and probiotic co-supple- } \\
\text { mentation on glucosehomeostasis, inflammation, } \\
\text { oxidative stress and pregnancy outcomesin } \\
\text { gestational diabetes: A randomized, double-blind, } \\
\text { Q3 plasebo-controlled trial }\end{array}$ & Iran & $\mathrm{RCT}$ & 58 & $\begin{array}{l}\text { Pregnant } \\
\text { women }\end{array}$ \\
\hline Asemi et al. & Vitamin D3 alters Toll-like receptor 4 signaling in & China & $\mathrm{RCT}$ & 60 & Pregnant \\
\hline
\end{tabular}


Fajriyani et al./ Vitamin D and Calcium Supplementation in Reducing Preeclampsia

\section{Calcium supplementation reduces the risk of preeclampsia}

a. Summary Source

Table 2. Descriptions of primary studies included in the meta-analysis

\begin{tabular}{|c|c|c|c|c|c|}
\hline $\begin{array}{l}\text { Author } \\
\text { (Year) }\end{array}$ & Titles & Country & $\begin{array}{l}\text { Study } \\
\text { Design }\end{array}$ & Sample & $\begin{array}{c}\mathbf{P} \\
\text { Population }\end{array}$ \\
\hline $\begin{array}{l}\text { Azar et al. } \\
(2015)\end{array}$ & $\begin{array}{l}\text { Calcium supplementation in pregnancy and } \\
\text { preventionof hypertensive disorders in } \\
\text { elderly women }\end{array}$ & Iran & $\mathrm{RCT}$ & 80 & $\begin{array}{l}\text { Pregnant } \\
\text { women }\end{array}$ \\
\hline $\begin{array}{l}\text { Khomar et al. } \\
\text { (2009) }\end{array}$ & $\begin{array}{l}\text { Calcium supplementation for the } \\
\text { prevention of pre-eclampsia }\end{array}$ & India & $\mathrm{RCT}$ & 80 & $\begin{array}{l}\text { Pregnant } \\
\text { women }\end{array}$ \\
\hline $\begin{array}{l}\text { Niromanesh } \\
\text { et al. (2001) }\end{array}$ & $\begin{array}{l}\text { Supplementary calcium in prevention of } \\
\text { pre-eclampsia }\end{array}$ & Iran & $\mathrm{RCT}$ & 60 & $\begin{array}{l}\text { Pregnant } \\
\text { women }\end{array}$ \\
\hline $\begin{array}{l}\text { Hofmayr et } \\
\text { al. (2016) }\end{array}$ & $\begin{array}{l}\text { Prepregnancy and early pregnancy calcium } \\
\text { supplementation among women at high risk } \\
\text { of pre-eclampsia: a multicentre, double- } \\
\text { blind, randomised, plasebo-controlled trial }\end{array}$ & $\begin{array}{l}\text { Afrika } \\
\text { Selatan }\end{array}$ & $\mathrm{RCT}$ & 141 & $\begin{array}{l}\text { Pregnant } \\
\text { women }\end{array}$ \\
\hline $\begin{array}{l}\text { Taherian et } \\
\text { al. (2002) }\end{array}$ & $\begin{array}{l}\text { Prevention of preeklampsia with low-dose } \\
\text { aspirin or calcium supplementation }\end{array}$ & Iran & $\mathrm{RCT}$ & 330 & $\begin{array}{l}\text { Pregnant } \\
\text { women }\end{array}$ \\
\hline $\begin{array}{l}\text { Khan et al. } \\
\text { (2013) }\end{array}$ & $\begin{array}{l}\text { Role of high dose calcium in the prevent of } \\
\text { preeklampsia }\end{array}$ & India & $\mathrm{RCT}$ & 272 & $\begin{array}{l}\text { Pregnant } \\
\text { women }\end{array}$ \\
\hline $\begin{array}{l}\text { Carole et al. } \\
\text { (2019) }\end{array}$ & $\begin{array}{l}\text { Comparative effect of calcium supplemen- } \\
\text { tation on the incidence ofpre-eclampsia and } \\
\text { eclampsia among primigravida women }\end{array}$ & Cameroon & $\mathrm{RCT}$ & 70 & $\begin{array}{l}\text { Pregnant } \\
\text { women }\end{array}$ \\
\hline $\begin{array}{l}\text { Samimi et al. } \\
(2017)\end{array}$ & $\begin{array}{l}\text { The effects of vitamin D plus calcium } \\
\text { supplementation on Metabolic profiles, } \\
\text { biomarkers of inflammation, oxidative }\end{array}$ & Iran & $\mathrm{RCT}$ & 60 & $\begin{array}{l}\text { Pregnant } \\
\text { women }\end{array}$ \\
\hline
\end{tabular}


Fajriyani et al./ Vitamin D and Calcium Supplementation in Reducing Preeclampsia

\section{c. Forest Plot}

\begin{tabular}{|c|c|c|c|c|c|c|c|c|c|c|c|}
\hline Study or Subgroup & \multicolumn{2}{|c|}{ Kalsium } & \multicolumn{2}{|c|}{ Plasebo } & \multicolumn{3}{|c|}{ Risk Ratio } & \multicolumn{3}{|c|}{$\begin{array}{c}\text { Risk Ratio } \\
\text { IV, Fixed, } 95 \% \mathrm{Cl} \\
\end{array}$} & \\
\hline Aghamohammadi 2015 & 6 & 44 & 14 & 45 & $11.9 \%$ & $0.44[0.19,1.04]$ & & & & & \\
\hline Carole 2019 & 1 & 35 & 7 & 35 & $2.1 \%$ & $0.14[0.02,1.10]$ & & & & & \\
\hline Hofmeyr 2019 & 14 & 69 & 23 & 72 & $26.6 \%$ & $0.64[0.36,1.13]$ & & & & & \\
\hline Khan 2013 & 7 & 123 & 19 & 139 & $12.8 \%$ & $0.42[0.18,0.96]$ & & & & & \\
\hline Kumar 2009 & 11 & 273 & 30 & 251 & $19.7 \%$ & $0.34[0.17,0.66]$ & & & & & \\
\hline Niromanesh 2001 & 1 & 15 & 7 & 15 & $2.3 \%$ & $0.14[0.02,1.02]$ & & & & & \\
\hline Samimi 2017 & 1 & 30 & 3 & 30 & $1.8 \%$ & $0.33[0.04,3.03]$ & & & & & \\
\hline Taherian 2002 & 13 & 330 & 33 & 330 & $22.8 \%$ & $0.39[0.21,0.73]$ & & & & & \\
\hline Total $(95 \% \mathrm{Cl})$ & & 919 & & 917 & $100.0 \%$ & $0.42[0.31,0.57]$ & & & & & \\
\hline Total events & 54 & & 136 & & & & & & & & \\
\hline $\begin{array}{l}\text { Heterogeneity: } \mathrm{Chi}^{2}=4.7 \\
\text { Test for overall effect: } \mathrm{Z}=\end{array}$ & $\begin{array}{l}d f=7(P \\
69(P<0\end{array}$ & $\begin{array}{l}=0.70 \\
0.0000\end{array}$ & ;) $\left.\right|^{2}=0 \%$ & & & & 0.01 & 0.1 & Kalsium & plasebo & 100 \\
\hline
\end{tabular}

\section{Figure 3. Forest plot of the effect of calcium supplementation on reducing the risk of preeclampsia}

The results of the forest plot (Figure 3) show that calcium supplementation reduces the risk of preeclampsia. The metaanalysis of RCT studies showed that malaria infection increased the incidence of LBW by 0.42 times compared to placebo and was statistically significant $(\mathrm{p}<0.001)$. The heterogeneity of the research data shows that $\mathrm{I}^{2}=0 \%$ so that the spread of

\section{d. Funnel Plot}

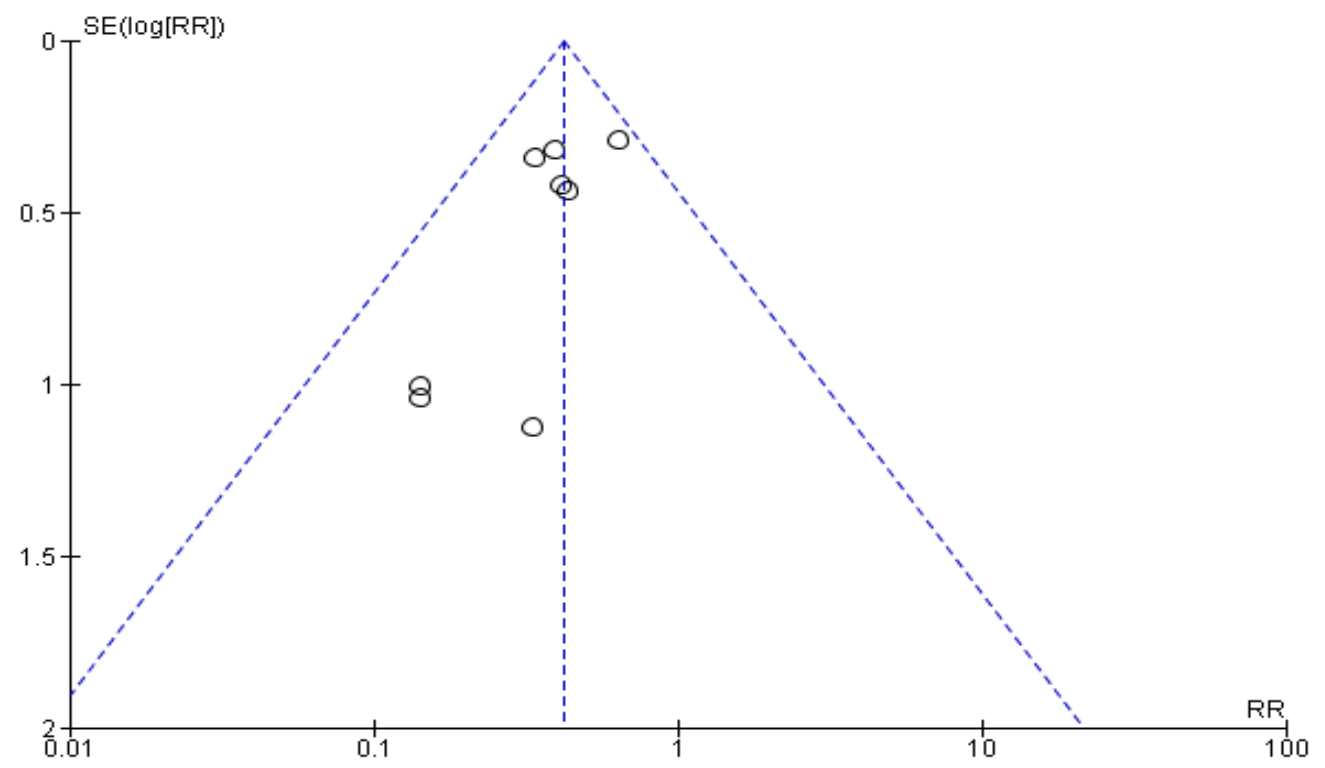

Figure 4. Funnel plot of the effect of calcium supplementation on reducing the risk of preeclampsia data is declared homogeneous (fixed effect model).

The funnel plot (Figure 4) shows a publication bias which is characterized by asymmetry of the right and left plots where 1 and 1.5 and the right side plot have a standard error between 0 and 0.5 The bias also occurs from an imbalance between the distances between studies both on the right and left funnel plot. 
Fajriyani et al./ Vitamin D and Calcium Supplementation in Reducing Preeclampsia

Table3. Critical Appraisal Checklist for Randomized Controlled Trial

\begin{tabular}{|c|c|c|c|c|c|}
\hline Checklist of Questions & $\begin{array}{l}\text { Sasam } \\
\text { n et al. } \\
(2017)\end{array}$ & $\begin{array}{l}\text { Samim } \\
\text { i et al. } \\
(2017)\end{array}$ & $\begin{array}{l}\text { Sablok } \\
\text { et al. } \\
(2015) \\
\end{array}$ & $\begin{array}{l}\text { Roth et } \\
\text { al. } \\
\text { (2013) }\end{array}$ & $\begin{array}{l}\text { Karamali } \\
\text { et al. } \\
(2015)\end{array}$ \\
\hline $\begin{array}{l}\text { Does the research clearly address the focused } \\
\text { statement / problem? }\end{array}$ & 1 & 1 & 1 & 1 & 1 \\
\hline $\begin{array}{l}\text { Is the Randomized Controlled Trial research } \\
\text { method suitable for answering research } \\
\text { questions? }\end{array}$ & 1 & 1 & 1 & 1 & 1 \\
\hline $\begin{array}{l}\text { Are there enough subjects in the study to } \\
\text { establish that the findings were not made by } \\
\text { chance? }\end{array}$ & 1 & 1 & 1 & 1 & 1 \\
\hline $\begin{array}{l}\text { Were subjects randomly allocated to the } \\
\text { experimental and control groups? If not, could } \\
\text { this be biased? }\end{array}$ & 1 & 1 & 1 & 1 & 1 \\
\hline Are inclusion / exclusion criteria used? & 1 & 1 & 1 & 1 & 1 \\
\hline $\begin{array}{l}\text { Were the two groups comparable at study } \\
\text { entry? }\end{array}$ & $\mathrm{O}$ & $\mathrm{O}$ & $\mathrm{O}$ & $\mathrm{O}$ & 1 \\
\hline Are objective and unbiased outcome criteria? & 1 & 1 & 1 & 1 & 1 \\
\hline $\begin{array}{l}\text { Are objective and validated measurement } \\
\text { methods used to measure the results? If not, } \\
\text { were the results scored by someone who did } \\
\text { not know the group assignment (i.e. was the } \\
\text { grading blended)? }\end{array}$ & 1 & 1 & 1 & 1 & 1 \\
\hline Is the effect size practically relevant? & 1 & 1 & 1 & 1 & 1 \\
\hline How precise is the estimated effect? Is there a & $\mathrm{O}$ & $\mathrm{O}$ & $\mathrm{O}$ & $\mathrm{O}$ & 1 \\
\hline
\end{tabular}


Fajriyani et al./ Vitamin D and Calcium Supplementation in Reducing Preeclampsia

Table 4. Critical Appraisal Checklist for Randomized Controlled Trial

\section{Checklist of Questions}

Does this objective clearly address the focus / research problem? Is the research method (research design) appropriate for answering research questions?

Is the method of selecting research subjects clearly written?

Can the sampling method

introduce bias (selection)?

Does the research sample taken

represent the designated

population?

Was the sample size based on prestudy considerations?

Was a satisfactory response achieved?

Are the research instruments valid and reliable?

Is statistical significance assessed? Are confidence intervals given for the main outcome?

\section{Alghamohammadi \\ Carole et al. \\ Hofmeyr} et al. (2015)

1

1

1

1

1

O

1

1

1

O
(2019)

1

1

1

1

1

1

1

1

1

1 et al.

(2019)

1

1

1

1

1

Khan

et al.

(2013)

1

1

1

1

1

1

1

1

1

1

1
Khuma

et al.

(2009)

1

1

1

1

1

1

1

1

1

1 
Fajriyani et al./ Vitamin D and Calcium Supplementation in Reducing Preeclampsia

\section{DISCUSSION}

Preeclampsia in pregnancy is defined as the presence of hypertension as well as the presence of proteinuria in women after 20 weeks of gestation. Most of the maternal deaths caused by preeclampsia occur in developing countries and countries with low to middle income populations. The biggest impact of preeclampsia occurs in developing countries where the incidence of preeclampsia is $20-80 \%$ of the maternal mortality rate (Dodd et al, 2014).

\section{The effect of vitamin $D$ supplemen- tation on reducing the risk of pre- eclampsia in pregnant women}

There are 9 Randomized Controlled Trial articles as a source of meta-analysis of the effect of vitamin D supplementation on reducing the risk of preeclampsia. The analysis was carried out with the review manager application study design 5.4, the results were interpreted in the form of a forest plot and a funnel plot. The meta-analysis of the RCT study showed that malaria infection increased preterm delivery by 0.45 times compared to placebo and was statistically significant $(\mathrm{RR}=0.45,95 \% \mathrm{CI}=0.32-0.63$, $\mathrm{p}<0.001)$. The heterogeneity of the research data shows that $\mathrm{I}^{2}=0 \%$, so that the spread of data is declared homogeneous (fixed effect model.

The results of this study are in line with those of the Kanaga et al. (2014) study involving 219 pregnant women showing that women who received vitamin D supplements had a lower risk of preeclampsia than those who did not receive the intervention or placebo (8.9\% versus $15.5 \%$; $(\mathrm{RR}=0.52 ; 95 \% \mathrm{CI}=0.25$ to 1.05$)$. Giving vitamin D supplements to pregnant women increases levels of 25-hydroxyvitamin D at term gestation and can reduce the risk of preeclampsia, low birth weight and preterm birth.
The results of a study by Hypponen et al. (2013) indicated that low-dose vitamin D supplementation (400 IU/day) significantly reduced the risk of preeclampsia compared to the control group $(\mathrm{OR}=0.66$; 95\% CI 0.52-0.83). Pregnant women with preeclampsia, the placenta shows a strong inflammatory response and an increase in the activity of the immunological system. This suggests that the vitamin D immunomodulation system has the potential to benefit placental implantation during pregnancy. Adequacy of meeting the needs of vitamin D provides an immunomodulating effect and regulation of blood pressure. Other studies have shown supporting evidence about vitamin $\mathrm{D}$ levels which play a role in the early part of pregnancy in regulating risk factors for complications in pregnancy, supporting fetal growth, bone development and immune maturity.

2. The effect of calcium supplementation on reducing the risk of preeclampsia in pregnant women

There are 8 articles with the Randomized Controlled Trial study design as a source of meta-analysis of the effect of calcium supplementation on reducing the risk of preeclampsia. The results of the meta-analysis showed that calcium supplementation can reduce the risk of preeclampsia by 0.42 times compared to placebo $(\mathrm{RR}=0.42 ; 95 \%$ $\mathrm{CI}=0.31-0.57 ; \mathrm{p}=0.001)$.

The results of this study are in line with research conducted by Hofmeyr et al. 2019 with research subjects of pregnant women, where the results showed that respondents with more than $80 \%$ adherence to taking calcium supplements from their last visit before pregnancy to 20 weeks of gestation had a lower risk of preeclampsia. ie 30 (21\%) out of 144 versus pregnant women who did not consume calcium regularly ie. $47(32 \%)$ out of $149(\mathrm{RR}=0.66$, 95\% $\mathrm{CI}=0.44-0.98 ; \mathrm{p}=0.037)$. In this 
study no serious side effects of calcium were reported.

The dose of calcium supplementation ranges from $500 \mathrm{mg} /$ day to $2 \mathrm{~g} /$ day. One study demonstrated a statistically significant effect in a study using a $2 \mathrm{~g} /$ day dose $\left.\left(\begin{array}{lllll}R R & 0.39 & {[95 \%} & \text { CI } & 0.23-0.67\end{array}\right]\right)$. This suggests that the most effective dose for calcium supplements during pregnancy is 2 $\mathrm{g} /$ day and is given starting from the beginning of pregnancy (Uzan et al, 2011).

Lack of calcium intake can cause an increase in parathyroid hormone (PTH), which causes an increase in intracellular calcium. The increase in intracellular calcium will cause the smooth muscle of the blood vessels to experience vasoconstriction so that blood pressure increases. Increased blood pressure during pregnancy is a risk of developing preeclampsia (Harera, 2012).

When calcium intake is low, the body uses a series of mechanisms to maintain serum calcium ion levels. Ionized serum calcium concentration depends on adequate calcium intake. In preeclampsia, there is a decrease in extracellular calcium concentration with a low level of ionized serum calcium. Extracellular calcium concentrations are very important for synthesis in endothelium such as prostacyclin and NO, so that calcium deficiency is not only mineral deficiency but also associated with physiological effects caused by oxidative stress (Kanagal et al., 2014).

This meta-analysis concluded that an unhealthy diet high in fat, high sugar, high carbohydrates increased the risk of developing diabetes $(\mathrm{aOR}=1.65 ; 95 \% \mathrm{CI}=1.29$ to $2.11 ; \mathrm{p}<0.001)$. This meta-analysis combines 9 primary studies using cross-sectional designs from the countries of Swaziland, China, Ethiopia, Kenya, the United States, and Malaysia.

This meta-analysis concluded that an unhealthy diet high in fat, high sugar, high carbohydrates increased the risk of obesity in adults $(\mathrm{aOR}=1.42 ; 95 \% \mathrm{CI}=1.21$ to 2.66 ; $\mathrm{p}<0.001)$. This meta-analysis combines 9 primary studies using a cross-sectional design from Ghana, China, Romania, Kenya, Nepal, Ireland, Korea, and Ethiopia.

\section{AUTHOR CONTRIBUTION}

Linda is the main researcher who selected the topic, explored and collected research data. Yulia and Eti played a role in analyzing data and conducting research document reviews.

\section{CONFLICT OF INTEREST}

There is no conflict of interest in this study.

\section{FUNDING AND SPONSORSHIP}

This study is self-funded.

\section{ACKNOWLEDGEMENT}

We are very grateful to the database providers PubMed, Google Scholar and Springer Link.

\section{REFERENCE}

Ali AM, Alobaid A, Malhis TN, Khattab AF (2019). Effect of vitamin D3 supplementation in pregnancy on risk of pre-eclampsia - Randomized controlled trial. Clin Nutr. 38(2):557-563. https://doi.org/10.1016/j.clnu.2018.o 2.023 .

Aghamohammadi A, Zafari M (2015). Calcium supplementation in pregnancy and prevention of hypertensive disorders in elderly women. Science Asia, 41(4): 259-262. http://dx.doi.org/10.2306/scienceasia1513-1874.2015.41.259.

Asemi Z, Hashemi T, Karamali M, Samimi M, Esmaillzadeh A (2013). Effects of vitamin D supplementation on glucose metabolism, lipid concentrations, inflammation, and oxidative 
Fajriyani et al./ Vitamin D and Calcium Supplementation in Reducing Preeclampsia

stress in gestational diabetes: A double-blind randomized controlled clinical trial. Am J Clin Nutr. 98(6): 1425-1432. https://doi.org/10.3945/ajcn.113.072785.

Asemi Z, Tabassi Z, Heidarzadeh Z, Khorammian $H$, Sabihi SS, Samimi M (2012). Effect of calcium-vitamin D supplementation on metabolic profiles in pregnant women at risk for pre-eclampsia: A randomized plasebo-controlled trial. Pak J Biol Sci. 15(7): 316-324. https://doi.org/10.3923/pjbs.2012.316.324.

Bhutta ZA, Jai KD, Arjumand R, Michelle FG (2013). Evidence-based interventions for improvement of maternal and child nutrition: what can be done and at what cost. Lancet, 88(2): 599605. https://doi.org/10.1016/So1406736(13)60996-4.

Dodd JM, O’Brien C, Grivell RM (2014). Preventing pre-eclampsia are dietary factors. BMC Med, 12(7): 176. https://doi.org/10.1186/s12916-014-0176-4

Dror K, Daphna KCJ, Bellen F (2012). Evidence of association between fetomaternal vitamin D status, cord parathyroid hormone and bone- specific alkaline phosphatase, and newborn whole body mineral content. J Nutr, 4(9): 68-77. https://doi.org/10.3390/nu4020068.

Hofmeyr GJ, Betrán AP, Madliki MS, Cormick G, Stephen P, Fawcus S, Mose S, et al. (2015). Prepregnancy and early pregnancy calcium supplementation among women at high risk of preeclampsia: A multicentre, doubleblind, randomised, plasebo-controlled trial. The Lancet. 393(1): 330-339. https://doi.org/10.1016/So140-6736(18)31818-X.

Imdad A, Bhutta Z (2012). Effects of kalsium supplementation during preg- nancy on maternal, fetal and birth outcomes. Paediatr perinat epidemiol, 26(4): 138-152. https://doi.org/10.1111/j.1365-3016.2012.01274.x.

Jamilian M, Amirani E, Asemi Z (2019). The effects of vitamin $\mathrm{D}$ and probiotic co-supplementation on glucose homeostasis, inflammation, oxidative stress and pregnancy outcomes in gestational diabetes: A randomized, doubleblind, plasebo-controlled trial. Am J Clin Nutr. 38(5): 209-2105. https://doi.org/10.1016/j.clnu.2018.10.028.

Kanagal DV, Rajesh A, Rao K, Devi UH, Shetty H, Kumari S, Shetty PK. (2014). Levels of serum kalsium and magnesium in pre-eclamptic and normal pregnancy: a study from coastal. India. J Clin Diagn Res. 8(7): OCo1OCo4. https://dx.doi.org/10.7860\%2FJCDR\%2F2014\%2F8872.4537.

Karamali M, Beihaghi E, Mohammadi AA, Asemi Z (2015). Effects of high-dose Vitamin D supplementation on metabolic status and pregnancy outcomes in pregnant women at risk for preeclampsia. Horm Metab Res, 47(12): 867-872. https://doi.org/10.1055/s0035-1548835.

Khan A, Mandal SK, Pal A. (2013). Role of high dose calcium in the prevention of preeclampsia. Bangladesh Journal of Obstetrics and Gynecology, 28(2), 66-70. https://doi.org/10.3329/bjog.v28i2.30092.

Kumar A, Devi SG, Batra S, Singh C, Shukla DK (2009). Calcium supplementation for the prevention of pre-eclampsia. Int J Gynaecol Obstet, 104(1): 32-36. https://doi.org/10.1016/j.ijgo.2008.o 8.027.

Naghshineh E, Sheikhaliyan S (2016). Effect Vitamin D supplementation in the reduce risk ofpre eclampsia in nulliparous women. Adv Biomed, 
Fajriyani et al./ Vitamin D and Calcium Supplementation in Reducing Preeclampsia

95(1): 7-7. https://dx.doi.org/10.4103\%2F2277-9175.175239.

Niromanesh S, Laghaii S, Mosavi JA (2001). Supplementary calcium in prevention of pre-eclampsia. Int $\mathrm{J}$ Gynaecol Obstet, 74(1): 17-21. https://doi.org/10.1016/So140-6736(18)31818-X.

Roth DE, Al Mahmud A, Raqib R, Akhtar E, Perumal N, Pezzack B, Baqui AH (2013). Randomized plasebo-controlled trial of high-dose prenatal thirdtrimester vitamin D3 supplementation in Bangladesh: the AViDD trial. Int J Obes. 12(1): 1-16. https://doi.org/10.1186/1475-2891-12-47.

Sablok A, Batra A, Thariani K, Batra A, Bharti R, Aggarwal AR, Kabui BC, et al. (2015). Supplementation of Vitamin $\mathrm{D}$ in pregnancy and its correlation with feto-maternal outcome. J Clin Endocrinol. 83(4): 536-541. https://doi.org/10.1111/cen.12751.

Santorelli G, Whitelaw D, Farrar D, West J, Lawlor DA (2019). Associations of maternal vitamin D, PTH and calcium with hypertensive disorders of pregnancy and associated adverse perinatal outcomes: Findings from the Born in Bradford cohort study. Sci Rep. 9(1):1205. https://doi.org/10.1038/s41598-018-37600-9.

Samimi M, Kashi M, Foroozanfard F, Karamali M, Bahmani F, Asemi Z, Hamidian Y, et al. (2016). The effects of vitamin D plus calcium supplementation on metabolic profiles, biomarkers of inflammation, oxidative stress and pregnancy outcomes in pregnant women at risk for pre-eclampsia. J Hum Nutr Diet, 29(4): 505-515. https://doi.org/10.1111/jhn.12339.

Taherian AA, Taherian A, Shirvani A (2002). Prevention of preeklampsia with low-dose aspirin or calcium supplementation. Arch Iran Med, 5(3): 151-156. https://doi.org/10.1111/tog.12111.

WHO. (2017). Maternal Mortality Rate. World Health Organization, https://apps.who.int/iris/handle/10665/434 44 . 